\title{
Beliefs of Pre-Service Teachers about English language Teaching: Course and Practice
}

\author{
Creencias de estudiantes en formación docente \\ sobre la enseñanza del inglés: curso y práctica
}

Crenças de estudantes em formação docente
sobre o ensino de inglês: curso e prática

Norma Constanza Durán Narváez
Sandra Patricia Lastra Ramírez
Adriana María Morales Vasco

Resumen

El presente estudio, cuyo propósito principal consistió en develar las creencias acerca de las estrategias de enseñanza del inglés por parte de los profesores en formación, exploró el origen de dichas creencias y su reconstrucción y evolución, a raíz del efecto causado en ellas por los cursos de Didácticas y Práctica Docente. Los instrumentos usados en este estudio de caso de tipo cualitativo, exploratorio y descriptivo fueron las historias de aprendizaje (language learning histories) de los participantes, entrevistas, diarios de reflexión, portafolios de enseñanza y observaciones de clase. Los resultados mostraron la evolución de las creencias de los docentes en formación a medida que avanzaron en el programa académico. De la misma manera, se develaron sus filosofías de enseñanza renovadas. Finalmente, se evidenció la forma como los participantes de este estudio percibían a sus estudiantes y a sí mismos: a los primeros, como los principales actores en el proceso de enseñanza-aprendizaje, y a sí mismos, como agentes de cambio cuyo mejoramiento permanente y crecimiento profesional estuvieron mediados por la reflexión constante.

\section{Palabras clave}

Creencias, enseñanza del inglés, aprendizaje de los estudiantes en formación docente, filosofía de enseñanza, reflexión

\section{Abstract}

This research study, aimed to unveil pre-service teachers' beliefs about English teaching strategies, inquired about the origin of those beliefs, and also the effect that Didactics and Teaching Practicum courses had on their reconstruction and evolution. The instruments used in this qualitative, exploratory and descriptive case study were the students' language learning histories, interviews, students' reflection journals, teaching portfolios and classroom observations. The findings showed the initial student-teachers' beliefs about language teaching and learning and their transformation as they went through the teacher education program. Likewise, they showed their renewed teaching philosophies about pedagogical processes in language teaching. Finally, it was also evidenced the way they viewed their students as main actors in the process of learning, and themselves as agents of change whose improvement and professional growth was mediated by ongoing reflection.

\section{Keywords}

Beliefs, English teaching, pre-service teachers' learning, teaching philosophy, reflection

1 Universidad del Tolima, Ibagué, Colombia. Correo electrónico: ncduran@ut.edu.co.

2 Universidad del Tolima, Ibagué, Colombia. Correo electrónico: splastra@ut.edu.co.

3 Universidad del Tolima, Ibagué, Colombia. Correo electrónico: ammoralesv@ut.edu.co. 


\section{Resumo}

0 presente estudo, cujo propósito principal foi revelar as crenças acerca das estratégias do ensino de inglês dos professores em formação, explorou a origem dessas crenças e sua reconstrução e evolução, a partir do efeito causado nelas pelas aulas de Didáticas e Prática Docente. Os instrumentos utilizados no estudo de caso de tipo qualitativo, exploratório e descritivo foram as histórias de aprendizagem (language learning histories) dos participantes, entrevistas, jornais de reflexão, portfólios de ensino e observações de aula. Os resultados revelaram a evolução das crenças dos docentes em formação no transcurso do programa académico. Igualmente, foram reveladas suas filosofias de ensino renovadas. Finalmente, evidenciou-se a percepção dos participantes desse estúdio sobre seus alunos e sobre si mesmos: os primeiros, como os principais atores no processo de ensino-aprendizagem e, de si mesmos, como agentes de cambio cujo desenvolvimento permanente e crescimento professional estiveram mediados pela reflexão constante.

\section{Palavras chave}

Crenças, ensino do inglês, aprendizagem dos estudantes em formação docente, filosofia do ensino, reflexão.

\section{Artículo recibido el 12 de febrero de 2016 y aprobado el 5 de agosto de 2016}

\section{Introduction}

The responsibility of teacher education programs in crafting the knowledge base as well as the praxis of prospective teachers is certainly overriding. In this sense, it is relevant for these types of programs to have a clear comprehension of the implications of becoming a language teacher. A vital component of these processes is the belief systems students bring with them to the programs, and how they are subject of transformation as they determine their actions and decisions in school contexts. As a consequence, this study explored the student-teachers' beliefs in a teacher education program, the dynamics of those beliefs and the way they nurtured the student-teachers' pedagogical practices in correspondence with the current Colombian demands in foreign language teaching.

The study was supported on concepts of beliefs as mental constructs, based on students' previous experiences (Pajares, 1992) and Jhonson's (2009) idea of beliefs as a result of participation in communities of practice which shape the way students see themselves as well as teaching and learning. Furthermore, beliefs are widely validated in this exploration as dynamic, permeable and susceptible to be changed in the light of experience (Thompson, 1992).

This qualitative study is the result of a classroom experience documented in language learning histories, reflective journals, teaching portfolios, as well as interviews and class observations. Through these sources it was surprisingly observed the way students perceived their process of becoming teachers, their confrontation between previous knowledge and experiences with the growing knowledge base resultant of the coursework during the Didactics and Practicum courses. As a result, this study evidenced how the former pre-service teachers' experiences became a platform for the construction of their own belief system, and how those beliefs were configured and transformed.

The outcomes of this study enlightened ways of developing skills in pre-service teachers to explore their thinking. They implemented metacognitive modes and reflection about what they did, how they did it and why they did it during their teaching practicum. The significance of this project lies in the contribution it makes to teacher education programs with regard to attaining a more realistic studentteachers' profile. It also broadens the perspective of the work done in the pedagogical component of the programs to adjust them better to the challenging realities of the regional and national contexts. In conclusion, exploring student-teachers' conceptions becomes a way to explain and understand teachingeducation processes (Freeman \& Richards, 1996).

In the following sections we discuss the theoretical constructs that supported the study, describe the research design, and present the findings. Finally, we draw some conclusions and implications of this research. 


\section{Theoretical framework}

\section{Beliefs}

The concept of beliefs has undergone sound transformations. The literature has moved from a simplistic view of beliefs-previously seen as mental, stable and individual-, to a more complex view of beliefs as paradoxical, dynamic and contradictory (Barcelos, 2003; Barcelos \& Kalaja, 2003; Dufva, 2003; Kramsch, 2003). Beliefs can be clearly described as a generic term, which can be easily adapted to diverse contexts, including the pedagogic and didactic ones. In this connection, Pajares (1992) pointed out a comprehensive array of synonyms which characterize the concept of beliefs: “...attitudes, values, judgments, axioms, opinions, ideology, perceptions, conceptions, conceptual systems, preconceptions, dispositions, implicit theories, explicit theories, personal theories, internal mental processes, action strategies, rules of practice, practical principles, perspectives, repertoires of understanding, and social strategy [...]" (p. 309). He also stated that "beliefs are generally used to describe individual mental constructs, which are subjectively true for the person in question" (p. 307); idea that finds a perfect complement, for the purpose of this study, in Calderhead \& Robson's reports (1991, cited in Pajares, 1992), which explain that

... pre-service teachers held vivid images of teaching from their experiences as students, images that influenced interpretations and particular courses and classroom practices and played a powerful role in determining how they translated and utilized the knowledge they possessed and how they determined the practices they would later undertake as teachers. (p. 310)

Beliefs have also been described, not only as ecological, situated in context, emergent, socially and contextually constructed, but also as mediated elements, that is, they can be seen as instruments, available tools for us to use or not, depending on the situation, task, and people interacting with us (Alanen, 2003; Dufva, 2003).

Thus, with the aim of pursuing the matter forward, let us define beliefs from the educational standpoint. Borg (2001) provides a comprehensive definition:
... a belief is a position which may be consciously or unconsciously held, is evaluative in that it is accepted as true by the individual, and is therefore imbued with emotive commitment; further, it serves as a guide to thought and behavior... Beliefs play an important role in many aspects of teaching, as well as in life, since they are involved in helping individuals make sense of the world, influencing how new information is perceived and whether it is accepted or rejected. Beliefs colour memories with their evaluation and judgment, and serve to frame our understanding of events. (p. 2)

This concept of beliefs regarding the level of autonomy and decision making capacity, which embraces teachers' belief system is expanded by what Basturkmen, Loewen \& Ellis (2004) define as beliefs: "the term beliefs is defined as statements teachers make about their ideas, thoughts, and knowledge that are expressed as evaluations of what 'should be done', 'should be the case' and 'is preferable"' (p. 244).

To continue with this contextualization, it is now necessary to move onto a construct which is inextricably related to the previous definitions, that is, beliefs about teaching.

\section{Beliefs about teaching and their source}

Since the 1990s, the importance of teachers' beliefs has been well-documented in language teaching research (Borg, 2006; Breen, Hird, Milton, Oliver \& Thwaite, 2001), showing that teachers' pedagogical beliefs closely influence their instructional practices (Borg, 2003; Farrell \& Kun, 2008; Ng $\&$ Farrell, 2003) and decision-making in class and classroom interaction (Li, 2008; Li \& Walsh, 2011) because, as it is generally acknowledged, teachers develop through time certain theoretical beliefs, which may take different forms, depending on the factors influencing their emergence or the field being affected by them.

However, when it comes to definitions, there are some discrepancies, stated by Borg, which have to be highlighted. For instance, S. Borg (2003) does not 
employ the term teacher's beliefs as such, he rather uses the concept teacher cognition "to refer to the unobservable cognitive dimension of teaching-what teachers know, believe and think" (p. 80). He also defines the term teachers' pedagogical systems as the beliefs, knowledge theories, assumptions, and attitudes teachers hold about all aspects of their work.

Regarding beliefs about teaching specifically, Richards \& Lockhart (1994) assert that "it is not surprising that individual teachers bring to teaching very different beliefs and assumptions about what constitutes effective teaching" (p. 36). In fact, those are the traits which result evident to colleagues and learners; the characteristics that make teachers individual beings different from others, and which act upon their decision making in classrooms. As a matter of fact, those beliefs have an origin or a source.

In Richards \& Lockhart's (1994) view,

...teachers' belief systems are founded on the goals, values, and beliefs teachers hold in relation to the content and process of teaching, and their understanding of the systems in which they work and their roles within it. These beliefs and values serve as the background to much of the teachers' decision making and action, and hence constitute what has been termed the 'culture of teaching. (p. 30)

And, as they continue explaining, "teachers' beliefs are derived from a number of different sources... a) their own experience as language learners; b) experience of what works best; c) established practice; d) personality factors; e) educationally based or research-based principles; and, f) principles derived from an approach or method" (Richards \& Lockhart, 1994, pp. 30-31).

The ideas above are particularly important in this study, as we attempt to unveil and describe the course of pre-service teacher's beliefs which could become evident in their everyday teaching practice, as it will be expounded in the findings section of this paper.

\section{Pre-service teachers' beliefs-their course}

Approached from a multifaceted perspective, the list of sources above makes us think of the numerous ways in which beliefs influence teachers' attitudes and actions in and out of the classroom. That is why Karavas (1996, cited in Lorduy et al., 2009) supports that,

... teachers educational attitudes and theories although in many cases unconsciously held, have an effect on their classroom behavior, influence what students actually learn and are a potent determinant of teachers' teaching style. It means that what teachers believe is reflected in their attitudes and therefore this affects their classroom practice. (p. 35)

Yet, if we think of pre-service teachers as those individuals being influenced primarily by their teachers in elementary, then in high school and, now, in undergraduate programs, we find the perfect fitting place for Lortie’s (1975) “apprenticeship of observation" which elucidates how the years (pre-service) teachers spend as learners in classrooms and the way they shape teachers' conceptions of teaching affect what and how they learn, make sense of experience, and how they teach.

For more than two decades, the development of pre-service teachers' beliefs has attracted considerable attention and has inspired lots of research in TESOL, to such an extent that the impact that pre-service teacher education programs have on trainees has been examined and, certainly, yielded important conclusions. There exists strong research evidence coming from different parts of the world proving that beliefs are not static, as it was evident in this study.

Beliefs do change because of the influence of specific factors. Some of them are palpable in Mattheoudakis' (2007) study, which proved, in a 3 -year teacher education program, that the majority of student-teachers' beliefs did change, and became stronger as a result of, on one hand, the methodology courses they attended, and, on the other hand, the direct contact they had with students through their observation and practice teaching sessions.

Regarding regional and continental studies, we may quote, firstly, Castellanos's (2013) work, where the role of English pre-service teachers' beliefs about teaching in teacher education programs was explored. The study demonstrated that when teacher educators ascertain this principle, they clearly integrate it in 
their syllabi thus aiding pre-service teachers to be aware of their entering beliefs about teaching and to experience changes in them so that explicit beliefs guide and inform the act of teaching. Secondly, Fajardo's (2013) study: "Stated vs. enacted beliefs: looking at pre-service teachers' pedagogical beliefs through classroom interaction", where stated beliefs (as articulated in interviews) and enacted beliefs (as manifested in classroom interaction) were compared to show that it is possible to gain a fine-grained understanding of the relationship between beliefs and teaching practice. Thirdly, we may mention Cota \& Ruiz-Esparza's (2013) longitudinal study, which aim was to identify (Mexican) pre-service teachers' beliefs about English language teaching and learning at different stages of instruction while they were taking the teaching practice courses in the program. The latter is quite similar to Durán, Lastra \& Morales (2013), in which autobiographies were used as a way to explore student-teachers' beliefs about English language teaching in the Colombian context.

\section{Research Design}

\section{Research Method}

This was a qualitative exploratory case study aimed at describing pre-service teachers' beliefs about English teaching strategies, as well as exploring the origin of those beliefs, and the effect the Didactics and Teaching Practicum courses had on their beliefs reconstruction and evolution. These aims were compressed in the following research questions:

1. How do the B. A. in English student-teachers' beliefs about language teaching strategies develop throughout their didactics courses and teaching practicum?

2. Do the student-teachers' beliefs change as a result of reflection and didactics courses content? If so, how are they reflected on their teaching practice?

3. What are the dynamics of the studentteachers' beliefs about language teaching strategies during their didactics and teaching practicum courses?
In order to respond to the nature of the study, data collection methods such as language learning histories, interviews, journals, portfolios and class observation were selected. All these instruments offer a clear report of the participants' contributions which allowed a deep understanding of the studied event (Cohen, Manion \& Morrison, 2000).

\section{Participants}

Nine pre-service teachers from sixth semester of the English program at Universidad del Tolima-the only public university of the city- participated in this study. These students were in their pedagogical preparatory phase and were also about to start their teaching practice in various public schools of the city.

\section{Data Collection and Analysis}

The methodology used to gather data about the student-teacher's beliefs about English teaching strategies relies on an autobiographical writing (self-story) garnered and analyzed through a narrative method. The data were also collected through semi-structured interviews based on their stories, through journals, portfolios and videos of their own teaching practices. These last three instruments were constructed throughout their practicum courses.

The analysis dealt with two types of data: narratives which included the student-teacher's autobiographies, journals and portfolios. The second type of data was constituted by the interviews and videos of their teaching practices. For the analysis of the instruments we followed a holistic content approach proposed by Lieblich, Tuval-Maschiach \& Zilbert (1998), who state that when analyzing the data, we must listen to at least three voices: the voice of the narrator, the theoretical framework and the interpretations.

Holistic refers to the unit of analysis in which a section or an utterance is drawn from the narrative as a whole. The categorical or content analysis deals with the analytical study of the material by dividing it into smaller units of content. All in all, the narration is divided into parts and then organized into categories: 
1. Listening to what the participants were telling through an intensive reading of the autobiographies, journals, reflections of the portfolios and transcripts of the videotaped interviews.

2. Seeking the main or core events. After several readings the researchers highlighted the parts that were relevant to the whole narrative or text.

3. Revisiting the concepts and highlighted words to select the most significant ones, as a way of data reduction.

4. Identifying the core concepts or categories from the previous reduced data.

5. Selecting and separating out each part of the data that would answer each of the research questions.

The following is a brief description of each instrument and the process that was carried out to analyze them.

\section{Language Learning Histories or Autobiographies}

Autobiographies, according to Denzin (1989), are told by an individual within the framework of a particular set of experiences. Following some guiding questions (see appendix 1 ), the participants wrote autobiographies exhibiting their experiences, diverse events and actions they have experienced through their English learning process and have had a significant effect on their epistemologies and methodologies of teaching as student-teachers (Polkinghorne, 1995). These narratives were analyzed following the narrative analysis method proposed by Connelly \& Clandinin (1995), which implies three moments of analysis: the first one is reading to hear the author's voice; the second moment is mapping the narration, in which high intensity moments are identified and past, present and future experiences related to the participant's language learning are recounted (Richmond, 2002); and the third one is finding patterns and meaningful events.

\section{Interviews}

Semi-structured individual interviews were performed and videotaped in order to expand important events found after analyzing the narratives. Then, all these interviews were transcribed and browsed through. Several readings were carried out in order to hear the author's voice, identify patterns and significant events that might lead us to the answer of the research questions. As it was expected, the information collected with the previous instrument was confirmed and new categories emerged providing new insights that contributed to a better understanding of the object of study, as it will be described in the next section of this article.

\section{Portfolios and Journals}

During the Didactics and Practicum courses students constructed a portfolio that evidenced all the process they were involved in throughout their pedagogical preparatory stage. Portfolios included their reactions and reflections to readings performed in class, their self-evaluation of their teaching practices, and all the materials and lesson plans they used during their practicum. Journals, at the same time, kept record of their thoughts and experiences in the classroom and made evident those implicit events that took place during their preparation courses and the student-teachers' reflective process about their practices. Journals revealed their beliefs and conceptions about all the decisions taken in class.

These instruments were analyzed using the content analysis approach, which allows a deep interpretation of the content of text data following a systematic classification process of coding and identifying themes or patterns (Hsieh \& Shannon, 2005). This method also opens possibilities for making replicable and valid inferences from data to their context with the purpose of providing insights and deeper understandings of events or facts (Krippendorff, 1980). The main purpose using this method was, as Patton (2003) states, trying to identify meanings on students' belief system. 
After visiting several times these students' journals and portfolios, and based on Polit \& Beck's (2004) insights, we selected characterization, course and practice of student teachers' beliefs about English language teaching as the unit of analysis, which was tied to our research questions and research objectives. Afterwards, based on this unit of analysis, we designed a structured matrix (Appendix 2, Table 1), which involved eight aspects derived from the research questions we had defined for the study. Those aspects were: Subject matter content knowledge, Pedagogical content knowledge, Principles and strategies for teaching, Curricular knowledge, Change in perspectives throughout their process as student-teachers reflected in the portfolio, Beliefs, Incorporation of principles or concepts learned in the teaching courses, Philosophy of teaching, Student-teachers' development, growth or improvement. Each aspect involved subcategories which guided a more detailed analysis.

While reading the journals and the portfolios, the matrix was filled out by the researchers, in order to structure the data and, by using an open coding, we were able to identify new categories and/or enriched the preliminary ones.

\section{Class observation video-recorded classes}

This instrument was used in order to establish connections between students' oral discourse on English language teaching strategies, and their real practices in the classroom. Participants videotaped their classes individually. Later on, each video was seen several times and analyzed in order to validate the information that emerged from the analysis of the instruments mentioned above, and also to identify special events of the class that could expand the conceptions already unveiled through such instruments. A class observation form was used to record all the reflections that resulted from observing the videos and nurtured the matrix described above.

For the purpose of triangulating data, the researchers read individually the autobiographies and then they shared their analyses as a group. This led to establish some recurrent perspectives and so preliminary themes and units of meaning. The same process was followed with the transcripts of the interviews and the matrix for portfolios and journals until the definite categories were identified and defined, based on commonalities identified among the different data sources.

For validation of the information, and to complement the understanding and interpretation of the issues that had emerged related to students' beliefs, the researchers watched the videos of student-teachers' classes. Investigators' triangulation was also considered since it included their perspectives, both as researchers and as teacher educators, who took part in the educational process of the participants involved.

\section{Findings}

This section presents the outcomes of the study, which emerged as a result of the analysis of the data already described, and in response to the research questions stated at the outset of this research. The student-teachers' beliefs and their course are described in detail throughout these findings encompassing three related dimensions: their self-perception as teachers, their perceptions about learners and about teaching.

\section{New ways of seeing themselves as teachers}

After analyzing, comparing, and contrasting the outcomes of the instruments used, we found out that the student-teachers had modified greatly their "self-perception" as teachers. There was a renewed belief which was, actually, the answer to our second research question (Do the studentteachers' beliefs change as a result of reflection and didactics courses content? If so, how are they reflected on their teaching practice?). This was evidenced when pre-service teachers compared the so-called traditional methodology with their own classroom-based techniques and principles, and their pedagogical practice. They realized they were doing things differently.

First of all, the student-teachers discovered themselves as dynamic teachers, who had moved from the "traditional practices"-which permeated their language learning histories-to lively classes which regarded students as the center of teaching. With this instrument, we found the information we needed to respond our first research question (How do the $\mathrm{B}$. 
A. in English student-teachers' beliefs about language teaching strategies develop throughout their didactics courses and teaching practicum?). That is to say, we first had to unveil what their beliefs were, in order to be able to identify their development or dynamics.

Those "traditional practices" the studentteachers talked about were basically characterized, using their voices, by direct implementation of teacher-centered approaches, in which teacher talk normally exceeds student talk; instruction occurs frequently with the whole class, not in small cooperative groups; teachers rely heavily upon the textbook to guide curricular and instructional decision making or present pupils with purposeless decontextualized tasks, and the use of class time is largely determined by the teacher (Cuban, 1983).

This was supported and explained by participants in the study, when asked about their experiences as language learners, through portfolio writing and face-to-face interviews:

... recuerdo esas clases en las que durante todo ese tiempo fue el verbo to be. En ese tiempo fue bastante aburrido. Los profesores no tenían como esa otra forma de enseñar, siempre era copiando en el tablero, repetir, y copiar en el cuaderno y ya! (M interview).

... Tradicional es un proceso [...] que el profesor habla durante toda la clase, que no permite la interacción entre profesor y estudiante y llega es a dictar la clase y uno a copiar [...] (N interview).

This analysis and the adoption of pedagogical changes were made by the student-teachers because they did not want to perpetuate those "traditional practices". In their own words, those practices yield negative outcomes or, at worst, none.

Therefore, turning back to the concept of dynamic teachers, participants say those are the ones who

[...] allow interaction in class, motivate and encourage creative, participative and relaxing classroom environments; they are people who communicate their passion for teaching ( $\mathrm{L}$ interview).
In this regard-as observed in the videos and as stated in their journals and portfolios-the studentteachers' practices, cooperative work, and constant interaction among students and teachers were prevalent. This is strong evidence to enlighten our second research question (Do the student-teachers' beliefs change as a result of reflection and didactics courses content? If so, how are they reflected on their teaching practice?)

... los estudiantes trabajan, no de manera individual o aislada, sino colectiva y cooperativamente, en parejas y grupos pequeños, para después compartir con el grupo en pleno, ya sea sus reflexiones o los productos del trabajo en equipo [...] (M Language learning histories)

These are, at the same time, clear samples of how participants came to "humanize teaching" through their practices, not only by relating to their students in a more "personal" way (understanding their differences and respecting them as individuals and their personalities), but also planning studentcentered classes (prioritizing their likes, preferences and learning styles).

Finally, and as a by-product of the whole process, participants realized the huge importance it has and the great responsibility teaching entails. They understood the positive effect good pedagogical practices might have on students when carried out responsibly; they collected and analyzed first-hand information that helped them comprehend their social responsibility and that teachers can lead students to attain awesome objectives if so they wish.

\section{New ways of seeing the learners}

The findings of the study demonstrated that the pre-service teachers changed their perspective about their students' role, their neglected abilities and the opportunities for participation in their own learning. Put in simpler words, those discoveries helped us answering our third research question (What are the dynamics of the student-teachers' beliefs about language teaching strategies during their didactics and teaching practicum courses?), since as the student-teachers went through the B. A. program, 
they started to reshape their views about their learners by confronting the strong influence of the inadequate and frustrating experiences during their own language learning at school. In addition to this, most of the role models provided during the observation phases in the schools during their practicum were not ideal or coherent with the knowledge base they were constructing at the university. In consequence, they seemed to be very clear about their goal of not reproducing ineffective practices. Instead, they envisaged learners as capable beings, with potentialities, feelings and interests and, in short, individuals with a voice. Conversely, for the accomplishment of such a goal they pinpointed the opportunities and conditions teachers should create for learners to learn and the central role they should play in decision making in and outside the classroom.

One of the first aspects they attempted to do differently in their classes was to generate a sense of trust in their learners when they developed their classes entirely in English. This was rather a contrast with what usually happened in the English classroom in some contexts, supported on the commonplace idea that in large classes, students' behavior makes it hard to conduct English classes in English. This is a sad but a real situation which can be inferred from the next quotes:

... my tutor told me that it was the first time that this seventh graders had a teacher who developed the class in English and that the activities were engaging... (J- journal)

... the students think that they do not understand anything because the class is in English and they feel like frustrated; I know that receiving a class in English when you had it in Spanish is a shocking experience, an abrupt change... (C-journal)

The process of developing classes entirely in English was struggling at the beginning, especially because the student-teachers had to deconstruct their pupils' comfort zone and start building up disposition in their learners to interact with their partners by using the foreign language. For this reason, in the video-recorded classes the student-teachers exhibited a range of strategies such as body language, visual aids, paraphrasing, among others, which gradually created an environment of mutual reliance and helped and generated a growing feeling of achievement in their learners and in themselves as teachers.

I'm here learning from others, learning to trust myself, learning to trust my students and to do things in a different way. ( J-portfolio selfevaluation)

A second factor which appeared to be relevant in the analysis of the reflections, lesson plans and classes observed (as stated in the second research question) was the pre-service teachers' beliefs about their learners. That aspect has to do with the significant role of getting acquainted with their students' needs, preferences, learning styles to get their attention easier, to provide more realistic contexts for teaching, to involve more the learners and so create more motivating and tension-free environments suitable to learn the foreign language. The recognition of the value of such an important background for the teachers led them to make more sound and meaningful decisions at the time of choosing or designing and implementing materials. The outcome of this important inclusion was to have more lifelike, spontaneous and massive involvement of the learners during the classes, which derived in actual learning opportunities. The following excerpts show the student-teachers' criteria to select materials and the subsequent effects those materials had on the students' motivation.

I would highlight the materials and topics because we as teachers have to use real examples, real things. For example, in the first class students were so motivated with the map of Ibagué. The effect was that the students started to ask questions. In the second and third classes it was similar because they were based on real things like movies and music, something that students like a lot... (N-journal)

... I see how important the way that I choose the readings for my students is. They should be appealing to the students and we must know what are their likes and dislikes and the type of readings they enjoy... (J-journal) 
To explore further the students' preferences and interests, the pre-service teachers implemented surveys, questionnaires and informal chats. Their awareness of the relevance of knowing what their students preferred or hated became an unavoidable task to design activities and in general to pursue success in their classes.

... I made the needs analysis to my students in order to know what their likes and dislikes are [...] that information can be useful for our classes, in order to design the activities ... ( $\mathrm{N}$-journal)

I made the needs analysis and classroom language in order to know what students like and dislike, to know the students a little bit more as Maslow's hierarchy of needs says, we have to know about their fears, status, all that the students do. Who are the learners? And many other questions that can be useful for our classes in order to design the activities (J-Journal)

A third important issue which emerged from this exploration was the encouragement of collaborative work among pairs and groups in different moments of the classes. The implementation of this principle demonstrated not only the student-teachers' underlying new perceptions about their learners, but also the impact of these criteria in the selection of activities like projects, which evidenced students' teamwork where they supported and learned from each other, in the creation of stories, brochures, posters or cards among others as reflected in the following descriptions:

Students had to work in groups of five students on a project about how they were protecting the environment. Each group did a different project: bracelets, drawings, rosettes, etc. After that, each group explained what they did in their project and their message. (C-Self-evaluation)

They were working all the time in their project. The things they had to do were really engaging and interesting. Students without exception were designing their own band. They cut and drew and at the end some groups talked about their band. Of course I helped them with vocabulary. $(\mathrm{N}$ - journal)

\section{New ways of seeing teaching}

Throughout the analysis of the data collected along the study, there was a very evident interest on bringing a new vision on methodologies and procedures to be carried out in the English class. All with only one purpose-not to repeat the same story our participants lived as learners, but to offer new ways in which the teaching process could be more meaningful to students and more humanized. In that sense, a recurring theme in reflections, lesson plans and classes we observed was the conception of language teaching as a process

"Language teaching is a process that requires reflection and execution." (M. journal)

Students' evolving ideas about teaching established that language teaching is a process that requires a lot of methodological conditions to be developed. First, the necessity to provide realistic and meaningful contexts to facilitate learning. Create a safe-learning, entertaining and motivating atmosphere. The recognition of students' individuality, with potential and ways of learning, became an essential ingredient that was included in student-teachers' decision making regarding the selection, design and implementation of activities. As a result of including this aspect in strategies and classroom activities, student-teachers showed a sense of accomplishment and satisfaction to see the active and spontaneous participation of their students. The following excerpts exhibit all these new conceptions they have incorporated in their new ways to see English teaching.

I also realized the importance of students' motivation before a class, because if students feel happy to work they are open to learn everything and I can feel confident to give clear instructions and develop the activities in an easier way and lively... (F-journal)

I used some flashcards related to famous people; students were interested in the class because most of them like all those kind of people. I used the flashcards taking into account students' likes and by doing so, we can really motivate students and catch their attention... (N-journal). 
In addition, we could observe that the starting point of participants' beliefs about teaching English yields on their previous experiences as learners. Everything they have lived throughout their preschool, primary, and high school years defined their way to teach English. These conceptions are framed within traditional teaching, memorizing formulas and isolated words, translation and a language that was totally out of context and far away from their realities.

When I was in high school my teacher just informed but she never worried about students' understanding. (C-interview)

At school teaching was very traditional, the teacher used to write on the board and assigned repetitive exercises. I only studied the verb to be. I never learned a thing. (L-interview)

An undeniable factor that emerged as a decisive one in the students' reframed ways of seeing teaching was their course work at university. This, in fact, became a turning point for their conceptions about teaching. They found throughout the English courses and specially the Didactics and Practicum ones, new ways to teach English, new principles to be taken into account when teaching a foreign language. This shift in their conceptions is directly related to the construction of a new philosophy of teaching that is the result of reflecting upon their experiences in the Didactic and Practicum courses. This evolving philosophy involves conceptions about the use of language in class, finding new ways to teach English, and rediscovering themselves as teachers, along the discovery of new possibilities and new challenges.

\section{Conclusions}

Due to the fact that the teachers' belief system is directly linked to their practices, attitudes and decisions they make in the classroom, it is imperative for all teacher educators to explore this belief system and provide significant insights to improve educational as well as teaching-education processes.

This study not only identified the beliefs of student-teachers from the B.A in English program at Universidad del Tolima, but also made it evident that the core of beliefs these student-teachers have about their teaching practices has been the product of life experiences as learners. This has been a process of construction throughout their educational process. What Lortie (1975) called the "apprenticeship of observation". This study also demonstrated that those beliefs were not static, but were influenced and in most of the cases modified as a result of processes of reflection upon the teaching realities they had faced. In relation to the course of student-teachers' beliefs, this study informed teacher educators about the way pre-service teachers' beliefs were deconstructed and constructed, shaped or reshaped, as a result of relating previous experiences from elementary and high school with new ones, acquired at the university. Thus, the pedagogical knowledge constructed during their undergraduate studies allowed the students to construct their teaching philosophies.

Some of the most relevant changes in beliefs about teaching English strategies exposed studentteachers' determination to not to repeat unsuccessful models that they called "tradicionalistas". Instead, they appeared innovative and more aware of the role school students may have in language learning. This shift was reflected in pre-service teachers' new ways of conducting classes mostly in English, the students' interests, styles and contexts were considered for planning and execution, making the students the center of the process.

The use of journals, portfolios, interviews, and class observations as class assignments offers teacher educators a wide open window to look at what students know, think and believe, in contrast with their actual practice in the classroom. Through their implementation, student-teachers made implicit influences explicit, and consciously chose the kind of teacher they wanted to be.

Another remarkable insight of the study is the lack of alignment between the knowledge base that student-teachers constructed at the university and the contradictory and discouraging realities they faced at schools, which challenged student-teachers practices and made them explore more and better language learning possibilities and conditions. Ultimately, this event served as their platform for decision making regarding classroom practices in schools. 
One of the most significant lessons from this study for us as teacher researchers entails that the more the roles teacher educators play within the realm of teacher education, the wider the scope to understand student-teachers' processes.

\section{Future directions}

Pre-service teachers' beliefs have become increasingly important in order to challenge, rethink and, eventually, reform language teaching practices in higher education (Lortie, 1975). In consequence, it is advisable to devote some class time in didactics courses or during their teaching practicum, to explore the beliefs they bring to the program and to let them know the possible dynamics of beliefs according to what research like this one and theory have demonstrated.

Providing pre-service teachers with spaces where they can freely experiment and implement their ideas showing themselves as individuals eager to humanize teaching.

Didactics, Teaching Practicum and Research Seminars content should embrace a cross-cutting perspective that allows the students to make sense of their knowledge base and to encompass it with the praxis and demands of classroom life.

As a result of this study and to expand on the interpretation of the findings, the research group of the B. A. program has started a new research project that aims at fostering teacher development processes in the teachers who tutor pre-service teachers in different public high schools in the city. With this new exploration, the group pursues to bridge the gap between the formation of future teachers in the B.A. program and the required updated profile of the language teachers who support the practicum in schools.

Didactics and Practicum courses should be taught simultaneously since it enhances the possibility that the students make direct and proper connections between theory and practice. Furthermore, these courses should be preceded by a strong preparatory stage made up by language (English) and Linguistics, and complemented with Evaluation, Psycholinguistics and Sociolinguistics courses.

\section{References}

Alanen, R. (2003). A sociocultural approach to young learners' beliefs about language learning. In P. Kalaja \& A.M. Barcelos. (Eds.), Beliefs about sla: New research approaches (pp. 55-85). Dordrecht: Kluwer Academic Press.

Basturkmen, H., Lowen, S. \& Ellis, R. (2004). Teachers' stated beliefs about incidental focus on form and their classroom practices. Applied Linguistics, 25(2), 243-272.

Borg, M. (2001). Key Concepts in elt. Teachers' beliefs. ELT Journal, 55(2), 186-188.

Borg, M. (2005). A case study of the development in pedagogic thinking of a pre-service teacher. TESL-EJ, 9(2), 1-30.

Borg, S. (2003). Teacher cognition in language teaching: a review of research on what language teachers think, know, believe, and do. Language Teaching, 36(2), 81-109.

Borg, S. (2006). Teacher education and language education: Research and practice. London: Continuum.

Borg, S. (2009). Language teacher cognition. In A. Burns \& J. C. Richards. (Eds.), Second language teacher education (pp. 163-171). Cambridge: Cup.

Breen, M.P., Hird, B., Milton, M., Oliver, R. and Thwaite, A. (2001). Making sense of language teaching: teachers' principles and classroom practices. Applied Linguistics, 22 (4), 470-501.

Castellanos, J.J. (2013). The role of English pre-service teachers' beliefs about teaching in teacher education programs. Profile, 15(1), 195-206.

Clandinin, D.J. \& Connelly, F.M. (1995). Teachers' professional knowledge landscapes. New York: Teachers College Press.

Cohen, L., Manion, L., \& Morrison, K. (2000). Research methods in education. London: Routledge Falmer.

Cota G., S., D. \& Ruiz-Esparza B. (2013). Pre-service teachers' beliefs about language teaching and learning: A longitudinal study. Profile, 15(1), 81-95.

Cuban, L. (1983). How teachers taught. New York: Teachers College Press.

Denzin, N.K. (1989). Interpretive biography. Newbury Park, California: Sage.

Dufva, H. (2003). Beliefs in dialogue. In P. Kalaja \& A.M. Barcelos. (Eds.), Beliefs about SLA: New research approaches (pp. 131-151). Dordrecht: Kluwer Academic Press. 
Durán, N., Lastra, S. \& Morales, A. (2013). Autobiographies: A way to explore student-teachers' beliefs in a teacher education program. Profile, 15(2), 35-47.

Fajardo, A. (2013). Stated vs. enacted beliefs: looking at pre-service teachers' pedagogical beliefs through classroom interaction. Íkala Revista de Lenguaje y Cultura, 18(2), 37-57.

Farrell, T. S. C. \& Kun, S. T. K. (2008). Language policy, language teachers' beliefs, and classroom practices. Applied Linguistics, 29(3), 381-403.

Freeman, D. \& Richards, J. C. (1996). Renaming experience/reconstructing practice: Developing new understanding of teaching. In D. Freeman \& J.C. Richards (Eds.), Teacher learning in language teaching (pp. 221-241). Cambridge: CUP.

Hsieh, H. F. \& Shannon, S. E. (2005). Three approaches to qualitative content analysis. Qualitative Health Research, 15(9), 1277-1288.

Johnson, K. E. (1999). Understanding language teaching: Reasoning in action. Boston: Heinle \& Heinle.

Johnson, K. E. (2009). Second language teacher education. A sociocultural perspective. Routledge.

Kagan, D. (1992). Professional growth among preservice and beginning teachers. Review of Educational Research, 62(2), 129-170.

Kalaja, P., \& Barcelos, A.M. (Eds.). (2003). Beliefs about SLA: New research approaches. Dordrecht: Kluwer Academic Press.

Karavas-Doukas, E. (1996). Using attitude scales to investigate teachers' attitudes to the communicative approach. ELT Journal, 50(3), 187-198. In D. Lorduy, E. Lambraño G. Garcés, N. Bejarano (2009). In-service English teacher's beliefs about culture and language methodology: An exploratory research in Montería. Zona Próxima 11(1), 32-51.

Krippendorff, K. (1980). Content analysis: An introduction to its methodology. Sage.

Lieblich, A., Tuval-Mashiach, R., \& Zilber, T. (1998). Narrative research. Reading, analysis and interpretation. Thousand Oaks, CA: Sage.

Li, L. (2008). EFL teachers' beliefs about ICT integration in Chinese secondary schools (unpublished doctoral thesis). Queen's University, Belfast.

Li, L. (2012). Belief construction and development: Two tales of non-native English speaking student teachers in a TESOL programme. Novitas-Royal (Research on Youth and Language), 6(1), 33-58.
Li, L. \& Walsh, S. (2011). Seeing is believing: Looking at EFL teachers' beliefs through classroom interaction. Classroom Discourse, 2(1), 39-57.

Lortie, D. (1975). Schoolteacher: A sociological study. Chicago: Chicago University Press.

Mattheoudakis, M. (2007). Tracking changes in preservice EFL teacher belief in Greece: A longitudinal study. Teaching and Teacher Education, 23(8), 1272-1288.

Ng, E. K. J. \& Farrell, T. S. C. (2003). Do teachers' beliefs of grammar teaching match their classroom practices? A Singapore case study. In D. Deterding, A. Brown \& E. L. Brown. (Eds.), English in Singapore: Research on Grammar (pp.128-137). Singapore: McGraw-Hill.

Pajares, M. F. (1992). Teacher's beliefs and educational research: Cleaning up a messy construct. Review of Educational Research, 62(3), 307-332.

Patton, M. (2003). Qualitative research and evaluation methods. Thousand Oakes, CA: Sage.

Peacock, M. (2001). Pre-service EsL teachers' beliefs about second language learning: A longitudinal study. System, 29(3), 177-195.

Polit, D.F. \& Beck, C.T. (2004). Nursing research. principles and methods. Philadelphia, PA.: Lippincott Williams \& Wilkins.

Polkinghorne, D.E. (1995). Narrative configuration in qualitative analysis. International Journal of Qualitative Studies in Education, 8(1), 5-23.

Richards, J.C. \& Lockhart, C. (1994). Reflective teaching in second language classrooms. Cambridge: Cambridge University Press.

Richmond, H.J. (2002). Learners' lives: A narrative analysis. The Qualitative Report, 7(3), 2-3.

Ruiz, E., Castillo, E. (2013). Beliefs about language teaching. Different contexts and perspectives. México: Pearson Longman.

Thompson, A. G. (1992). Teachers' beliefs and conceptions: A synthesis of research. In D. A. Grouws. (Ed.), Handbook of research on mathematics teaching and learning (pp. 127-146). New York, USA: Macmillan. 
Universidad Pedagógica Nacional

Facultad de Humanidades

\section{Appendix 1}

\section{Questions that guided the student-teachers' learning histories based on Johnson (1999)}

1. In what ways has your personality influenced the way you learn. Have your teachers taken this into account when planning and executing their classes?

2. What language learning experiences have you had and how successful have they been?

3. From the teaching practices you have been exposed to throughout your language learning process, describe the ones you consider both effective and ineffective.

4. How has your experience as a language learner influenced your decision of becoming a language teacher?

\section{Appendix 2}

Table 1. Structured Matrix for Journal and Portfolio Analysis

Research questions:

1. How do the в. A. in English student-teachers' beliefs about language teaching strategies develop throughout their didactics courses and teaching practicum?

2. Do the student-teachers' beliefs change as a result of reflection and didactics courses content? If so, how are they reflected on their teaching practice?

3. What are the dynamics of the student-teachers' beliefs about language teaching strategies during their didactics and teaching practicum courses? 


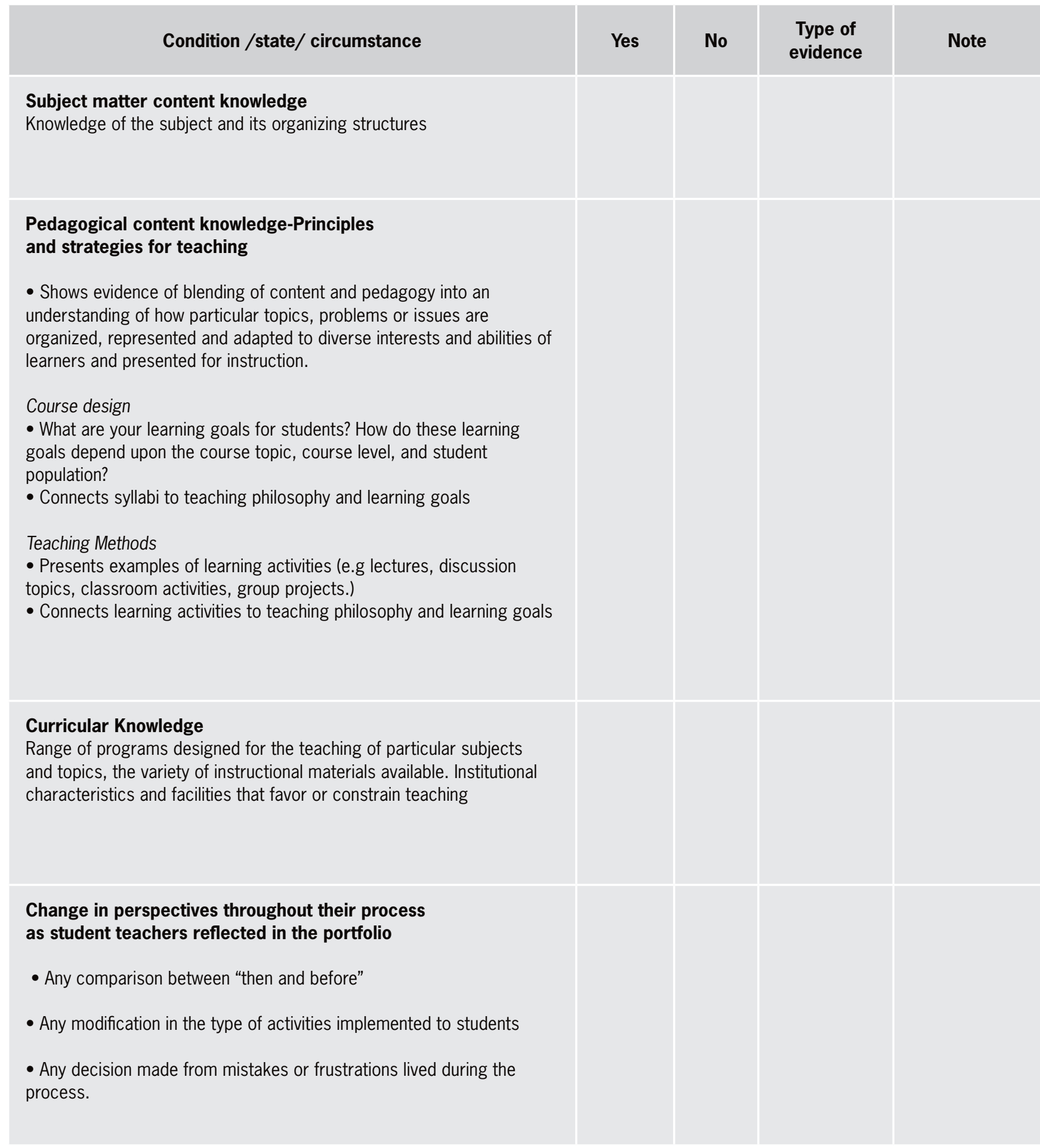


Universidad Pedagógica Nacional

Facultad de Humanidades

\begin{tabular}{|l|l|l|l|l|l|l|l|l|l|}
\hline Type of & Note \\
evidence
\end{tabular}

\section{Beliefs}

Teachers' perceptions or ideas about learners, teaching, learning

- How do they conceive the language teaching process?

- Language?

- Teaching strategies?

- Methodologies?

- Interactions?

- Personal role as a teacher?

\section{Philosophy of teaching}

Aims and goals teachers pursue in teaching.

- Teaching philosophy statement

Assessment of student learning

- Connects assignments to teaching philosophy and learning goals Assessment of teaching

- Connects trends in the teaching evaluation data to the teaching

philosophy and learning goals

-What principles are highlighted either in their activities or reflections?

- Is it evident any transformation in their

conceptions about language teaching?

\section{Incorporation of principles or concepts learned in the teaching courses}

- What pedagogical concepts are evident in the reflections?

- What teaching principles are present in student-teachers' activities and reactions?

- Is there any evidence of conceptions worked in class?

- Is there any reference to what they have read, discussed and worked in practicum or didactic courses?

\section{Student teachers' development, growth or improvement}

- Reflection on teaching:

- Aspects of teaching identified as weak and setting of a plan for improvement

- Connects teaching development plan to teaching and learning goals

- Demonstrates familiarity with pedagogical resources (general and disciplinary) to support teaching development

- What do I do? How do I do it? 
FOLIOS n. ${ }^{\circ} 45-193$

ISSN: 0123-4870 